\title{
Information Field in Malay Monolingual Dictionary
}

\author{
Chong Oi Chin (Corresponding author) \\ Department of Malay Language, Faculty of Modern Languages and Communication \\ University Putra Malaysia, 43400 Selangor, Malaysia \\ E-mail: chongoichin@gmail.com
}

Vijayaletchumy A/P Subramaniam

Department of Malay Language, Faculty of Modern Languages and Communication

University Putra Malaysia, 43400 Selangor, Malaysia

E-mail: letchumy@fbmk.upm.edu.my

Received: February 3, 2015 Accepted: February 25, 2015 Published: March 17, 2015

doi:10.5296/ijssr.v3i1.7042

URL: http://dx.doi.org/10.5296/ijssr.v3i1.7042

\begin{abstract}
The study of lexicography compares the information field between two Malay monolingual dictionaries, namely Kamus Dewan $\left(4^{\text {th }}\right.$ Edition) and Kamus Besar Bahasa Indonesia (4 ${ }^{\text {th }}$ Edition) known to be credible in Malaysia and Indonesia. Information field is the term used to refer to types of information contained in a dictionary such as spelling, pronunciation, meaning, grammar, etymology, word usage, cross-reference and other important aspects by compilers which are useful for the users. The study data comprise of 1087 entries which were selected using the easy and systematic approaches. The study adopts the library and content analysis methods. Data were analyzed descriptively. The objective identifies the content of the information field in both these dictionaries based on the use of the general principles of lexicography. Various aspects contained in the field or category of information in a dictionary. There are only three aspects that will be discussed in this study and they are word usage, etymology and cross-referencing. The study outcome shows that there are some differences, similarities and shortcomings in the information field of both dictionaries. The advantage offered by the findings of this study is that the use of the information field in a Malay monolingual dictionary helps the compilers to produce a credible dictionary.
\end{abstract}

Keywords: comparison, information field, Malay monolingual dictionary, entry, lexicography 


\section{Introduction}

Dictionary is perceived to be important as it has a direct relationship with language which is a tool of communication and a form of communication. The important role of language in every field of knowledge is irrefutable (Hishamudin \& Norshimah, 2011). Quoting Asmah (1993), language is an instinct or an indicator to a particular culture. Language also portrays the thinking and mirrors the identity of the speakers. It also determines the formation of thought based on the forms and categories contained within.

A dictionary enables scholars to analyze and learn about a knowledge field and scope. Other than that, a dictionary serves as a reference book containing information on words; and users refer to the dictionary to obtain certain information like spelling, pronunciation and meaning. (Fadilah, 1994). One of the dictionary aspects or lexicography is the meta-language. The information category or field is one of the important aspects in the meta-language of a dictionary arrangement. Information field is a term used to refer to the type of information from a dictionary such as spelling, pronunciation, meaning, grammar, etymology, word usage and others useful for the compilers and users of the dictionary (Fadilah, 1994; Mohd. Rasdi, 2012). Thus, the use of information field serves as a pattern of arrangement covering the aspects of descriptions and presentation of an entry in a dictionary. Information field does not only have some linguistics information, but it also details the non-linguistics information. Gleason (in Ibrahim, 1994: 103) states that the field of dictionary-making serves as a meeting point of all linguistics and non-linguistics systems, but it has also been explained by Zgusta (in Ibrahim, 1991: 603) as follows:

"The theory of lexicography is connected with lexical system, semantics, lexicology, grammar, stylistics, morphology ... the dictionary ... the meeting place of all systems linguistic and non-linguistic".

(Ibrahim Ahmad, 1991: 603)

Lawrence J. (1984) in his work entitled "Some Foundation of Lexicography in SEA Englishes", he enlists only five categories that a dictionary should have and they are spelling, pronunciation, as well as morphological, etymological and illustrative information. For other researchers like Edgar Dale et al. (1971) they opine that in general, the information field of a monolingual dictionary covers 15 aspects. They involve the root word or entry, word form, spelling and speech, word type, synonym and antonym, context of word use, definition, notes of word use, illustrations of definitions, derivatives, word use examples, phrase, quotations, foreign words and cross-reference. In this study, the category or field of information that shall be analysed with regards to both KD4 and KBBI4 covers only three categories namely word usage, etymology and cross-referencing.

\subsection{Problem Statement}

The issue raised in this study is on the use of the information field in Malay monolingual dictionaries, or specifically Kamus Dewan ( ${ }^{4 \text { th }}$ Edition) (or KD4) year 2010, published by Dewan Bahasa dan Pustaka (DBP); and Kamus Besar Bahasa Indonesia Pusat Bahasa ( ${ }^{4 \text { th }}$ Edition) (or KBBI4), year 2011, published PT Gramedia Pustaka Utama. The use of the 
information field in an arrangement of the dictionary is the main element in the field of lexicography or dictionary-making. In general, there is a scarcity of lexicography studies done by researchers either in Indonesia or Malaysia. The study outcome on Yusof (1961), Teeuw (1964), Ibrahim (1992), and Noresah (1993) are only general and chronological descriptions on the method of compiling a dictionary and the history of Malay Language dictionary-making. Other than that, studies by Asmah (1987), Ibrahim (1991, 2004), and Noresah $(1993,2009)$ generally describe the criteria essential in entry arrangements of a dictionary and the importance of Kamus Dewan as a general point of reference for the mass. However, all these studies have not been sufficient as there is no in-depth description on the information field in Malay monolingual dictionaries. Their studies have not been accompanied with examples of entries in monolingual dictionary comparison. Additionally, KD4 and KBBI4 are two general monolingual dictionaries and known as credible dictionaries for reference of other countries (Noresah et al., 2009). It is also rare to find researchers drawing a comparison between both the dictionaries. Obviously there is a paucity of studies regarding Malay dictionary-making especially drawing a comparison between Malaysian and Indonesian monolingual dictionaries. Therefore, a study on the comparison of the use of information field in KD4 and KBBI4 needs to be conducted in detail by including examples of the entries.

\subsection{Objective}

i. To identify the content of the information field in KD4 and KBBI4 arrangement based on the use of the general principles of lexicography.

\subsection{The Importance of Study}

In the context of this study, identifying the content of the information field in KD4 and KBBI4 is able to help the compilers to produce a monolingual dictionary and fulfil public needs especially the DBP (Kuala Lumpur, Malaysia) and Pustaka Utama (Jakarta, Indonesia). This is because both dictionaries are two great and general dictionaries of Malay Language that are the most authentic and serve as main reference to both native and non-native speakers. Therefore, this study is important to expose users or dictionary owners especially educators, students and academicians on the importance of information in a monolingual dictionary, that have all these while, left them in the dark on the importance of that kind of information. The outcome can also benefit the users on the rich knowledge contained in a dictionary and the criteria or characteristics that they need to know before they own a 'good' and 'comprehensive' dictionary.

\section{Literature Review}

From the literature, Asmah (1987) discusses on the production of a monolingual dictionary which clearly has its own intricacy, such as the complex interpretation or definition of an entry. Monolingual Malay dictionaries are still lacking in terms of putting forth their derivational words in terms of grammar, and also lacking the labeling to illustrate the social and pragmatic contexts in the discourse. For instance, Kamus Dewan does use the etymology label or word of origin like Arabic, Sanskrit, Javanese and so on. However, these labels are 
not thorough, and are only provided following the existing knowledge of the compilers at the time.

According to the study of Ibrahim (1991), he has observed the comparison of the information field between Kamus Dewan with Kamus Besar Bahasa Indonesia. The aspects of information field compared comprise of the aspects of entry, word form, speech and spelling, word-type, synonym, wording level, definitions or descriptions of language, wording note, definition-type descriptions, word derivations, phrases, loan word, foreign words and cross-reference. He gives an example of the entry 'juang' for Kamus Dewan and 'adu' for Kamus Besar Bahasa Indonesia as the example of the analysis of the information field. Ibrahim (2004) also discusses the development of the Malay dictionary from the perspective of the dictionary typology based on the formal typology framework put forth by R. R. K. Hartmann. Several formal typology aspects have been elaborated in detail such as the aspects of the type of dictionary, coverage, format, medium, function, information category and language. Other than the linguistic information display, the descriptions of information in the dictionary cover diachronic or etymological information; synchronic involving spelling, pronunciation and grammar; meaning description or definition; paradigmatic information like synonyms, antonyms and homonyms; syntagmatic information namely the Example of use and collocation; and the diasystematic information.

For the article by Noresah (1993) it concentrates more on the aspect of the formation of Kamus Dewan and the elements inside, namely the corpus resources, the spelling system, the dictionary entry, word borrowing management, dialectical words, technical words and homonym words. Also included is her evaluation towards Kamus Dewan. She also links the dictionary entry involving the number of entry with the types of words forming the entries. Concerning the dialectical words in Kamus Dewan, she posits that there is an inconsistency in the distribution of dialectical words between one district and another. This is made evident through the statistics done, where it is found that the dialects of Kelantan, Kedah, and Terengganu have far exceeded other states in the distribution of dialects found in Kamus Dewan. Noresah (2009) also elaborates on 'Kamus Dewan' specifically with regards to the history of the arrangement of Kamus Dewan from the first edition in 1970 to its latest edition published in 2005. She explains the method in compiling Kamus Dewan, finding the materials and the corpus data used in the production of a credible dictionary for public reference. It is thought that a more comprehensive dictionary cannot come at a better time, today. With the new monolingual dictionary being published, this does not mean that Kamus Dewan will continue to be abandoned, but it needs to lean on the most authoritative dictionary existing, which is the Kamus Dewan itself. Apart from that, as long as there is yet to be published a Malay dictionary that can perform as well as Kamus Dewan, then Kamus Dewan will continue to be improved and updated in order to cater for the needs of the Malay Language users.

Also, the study of Fadilah (1994) elaborates on information category in the dictionary based on the DBP-published dictionary. Her writing is indeed, the pioneering piece on the tradition of the Malay meta-lexicography which touches on several important information categories in Malay dictionaries. The category of information includes the information on spelling, 
pronunciation, meaning, etymology, grammar and word usage.

All these studies except for the work of Fadilah (1994) have focused on the importance of a dictionary especially Kamus Dewan as the main dictionary in Malaysia. Other than the importance of Kamus Dewan, other essential information in the elaboration of entries or metalanguage is also crucial in the production of a Malay monolingual dictionary. As there are some things that need to be explained, this study needs to be done to identify the use of the information field that can help in the publication of an invaluable Malay monolingual dictionary used for public reference.

\section{Methodology}

The framework of the study used is based on the use of the general principles of lexicography guided by the review done by Béjoint (1994). He proposes three general principles contained in the metalanguage. The first is the language used to describe all lexical details of the language of the object chosen as the entry of the dictionary or the language which describes the object language. The second lies in the way this language presents the linguistics and non-linguistics information of the object language or the way it talks about the object. Thirdly, the conventions of lexicography used to represent this information. This study is confined to the fact that the aim and objective of identifying the field or category of information in both these monolingual dictionaries are important aspects in the compilation of a quality and credible monolingual dictionary. The study data total 1087 entries from both dictionaries, where they were selected systematically and manually using the random sampling approach. The approach used in this study is the content analysis method and library method. The former is used to analyze three main aspects in information field or category namely word usage, etymology and cross-referencing in KD4 and KBBI4. The latter is used in this study as there are related books used as reference as to obtain some useful facts other than giving the impact to the study materials. Other than that, researcher also looked for some additional reference materials from journals, working papers, theses, and so on as to obtain some support contents. The study instrument comprises of two monolingual dictionaries, and they are KD4 (2010) published by the DBP, Kuala Lumpur, Malaysia; and KBBI4 (2011) published by Balai Pustaka, Jakarta, Indonesia. The data obtained were analysed in both qualitative and quantitative manner.

\section{Study Findings}

\subsection{Word Usage}

This aspect refers to the suitability of a word used in certain contexts and situations (Fadilah, 1994: 6). Dictionary users can obtain word usage information by referring to the label guide used in an entry. The use of these labels gets to inform dictionary users if a word or a phrase can be used suitably in a certain context and situation. Both dictionaries place the word label information after the main entry and the limit of use marked by certain labels or symbols.

The analysis of findings shows that KD4 (2010) has two labels of ragam bahasa (language style) and bidang (field). There are six types of language style labels ark - arkaik, bp - bahasa percakapan, sl - sastera lama, bh - bahasa halus, bk - bahasa kasar, and sr - seruan. The 


\section{Macrothink}

label of field comes in 12 types such as Ubat - perubatan, Bio - biologi, Muz - seni muzik, Mat - matematik, Kim - kimia/sains nuklear, Lin - linguistik, and so on. Meanwhile for KBBI4 (2011) there are labels of language style, field and word class. The label of language style comes in three types ark-arkais, cak - ragam cakapan and kl - klasik. There are 17 types for the label of field: Kim - kimia, Isl - agama Islam, Ling - lingusitik, Lay - pelayaran, Dok - kedoktoran dan fisiologi, Mus - Musik, and so on. There are seven types of word class label which are $\mathrm{n}$ - nomina, a - adjektiva, v-verba, adv-adverbia, $p$ - partikel, pron pronominal, and num - numeralia. From the analysis outcomes of KD4 and KBBI4 about the total entry in the label of word usage, researcher is able to conclude this in Table 1 which is by displaying types and total number of entry for the label of word usage in both KD4 and KBBI4:

Table 1. Types and number of entry of the label of word usage in KD4 and KBBI4

\begin{tabular}{|c|c|c|c|}
\hline $\begin{array}{l}\text { Name } \\
\text { of Dict. }\end{array}$ & Type \& No of entry of Usage Label & Name of Dict. & Type \& No of entry of Usage Label \\
\hline $\begin{array}{l}\text { KD4 } \\
(2010)\end{array}$ & $\begin{array}{cc}\text { a) Label Ragam Bahasa (117) } \\
\text { - } & \text { ark - arkaik (60) } \\
\text { - } & \text { bp - bahasa percakapan (27) } \\
\text { - } & \text { sl - sastera lama (25) } \\
\text { - } & \text { bk - bahasa kasar (3) } \\
\text { - } & \text { bh - bahasa halus (1) } \\
\text { - } & \text { sr - seruan (1) } \\
& \\
\text { b) Label Bidang (45) } \\
\text { - } \quad \text { Ubat - perubatan (11) } \\
& \text { - Kim - kimia/sains } \\
& \text { nuklear (9) } \\
\text { - } & \text { Lin - linguistik (8) } \\
\text { - } & \text { Bio - biologi (4) } \\
\text { - } & \text { Fiz - fizik (3) } \\
\text { - } & \text { Muz - seni muzik (2) } \\
\text { - } & \text { Geo - geografi (2) } \\
\text { - } & \text { Mat - matematik (2) } \\
\text { - } & \text { Tks - tekstil (1) } \\
\text { - } & \text { Ast - astronomi (1) } \\
\text { - } & \text { Sej - sejarah (1) } \\
\text { - } & \text { ERT - ekonomi rumah } \\
& \text { tangga (1) }\end{array}$ & KBBI4 (2011) & 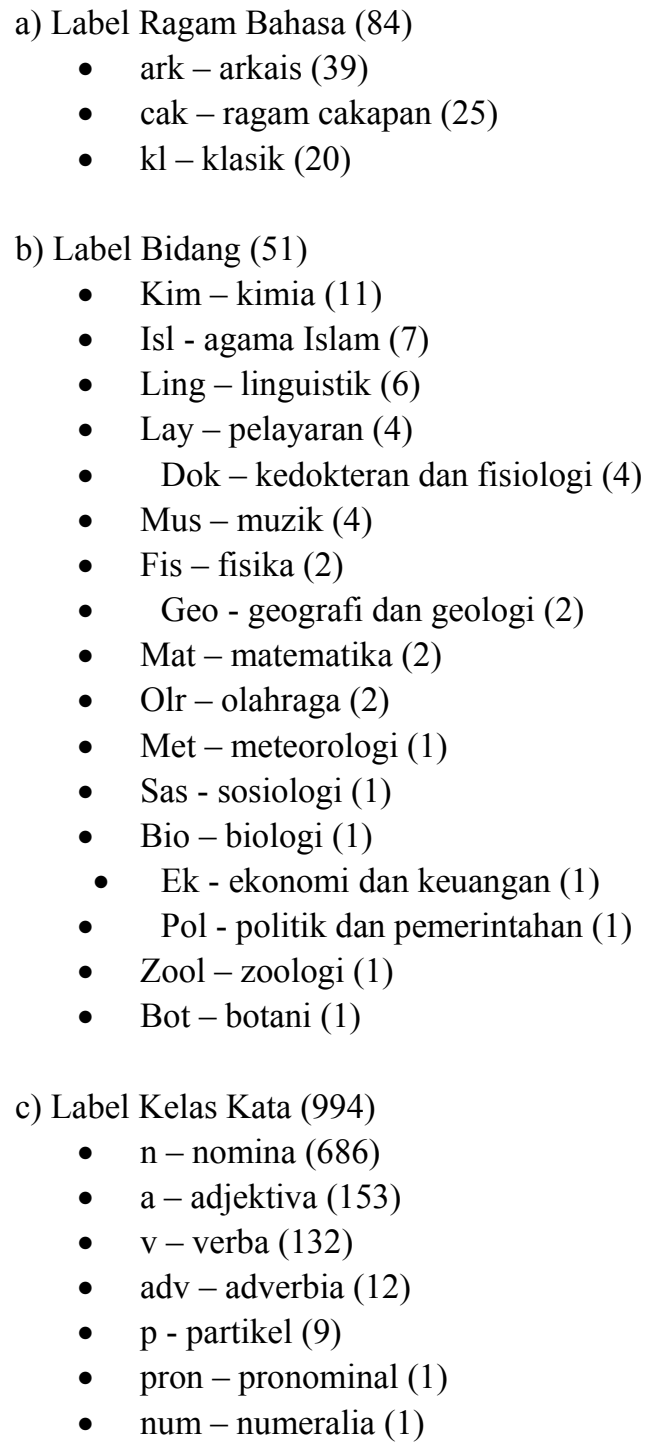 \\
\hline
\end{tabular}


From the table above, as many as 117 entries have used the label of language style. Label arkaik (ark) makes up the most, which is 60 entries in this study. This label is commonly used as a reminder that the word concerned is seldom used. Other than that, its used is confined to a particular district or area, or if the word is orthodox or obsolete, or if it is disputed due to ther fact that it may have been wrongly read, wrongly written, wrongly heard and so on (KD4, 2010: 1). The label of language style includes the language of speech which only covers 27 entries, old literature 25 entries, figurative language 3 entries and each entry for the label of exclamation and discreet language. The label of field in KD4 only shows 12 fields or 45 entries after being analysed by researcher. The label of field: Ubat - perubatan notes the highest number of entries which is 11 entries from the whole study data. 9 entries are from label Kim - kimia/sains nuklear; eight entries in Lin - linguistik; Bio - biologi 4 entries; Fiz fizik 3 entries; Muz - seni muzik, Mat - matematik dan Geo - geografi each with two entries; and, Tks - tekstil, Ast-astronomi, Sej - sejarah, and ERT - ekonomi rumah tangga only one entry. Example 1 shows the label of language style 'ark - arkaik' after the root entry of "dafnah". The label of 'Geog - geografi' applies for Example 2 "doldrum”.

Example 1

dafnah ark sj tumbuhan (pokok kecil) yg daunnya dibuat

mahkota pahlawan.

(KD4, 2010: 300)

Example 2

doldrum (Geog) zon angin tenang yg berhampiran dgn

khatulistiwa.

(KD4, 2011: 360)

For KBBI4, the language style label has 84 entries in three types of label namely ark - arkais (39 entries), cak - ragam cakapan (25 entries) and, kl - klasik (20 entries). The field label has 17 types or in total 51 entries. Among them are Kim - kimia (11 entries); Isl - agama Islam (seven entries); Ling - linguistik (six entries); Lay - pelayaran, Mus - musik dan Dok kedokteran dan fisiologi (four entries); Fis - fisika (two entries); Geo - geografi dan geologi, Mat - matematika, Olr - olahraga (two entries); Met - meteorologi, Sas - sosiologi, Bio biologi, Ek - ekonomi dan keuangan, Pol - politik dan pemerintahan, Zool - zoologi and Bot - botani (one entry). For the label of word class, 994 entries are found in this study. Label n nomina makes up he largect entries with 686 entries, then a - adjektiva 153 entries, $\mathrm{v}$ - verba 132 entries, adv - adverbia (12 entries), $\mathrm{p}$ - partikel nine entries, pron - pronominal and num - numeralia one entry each. Example 3 "ba.cut, ke.ba.cut" includes the label of word class ' $a d v$ - adverbia' first, and then 'cak - ragam cakapan' before the meaning is elaborated. As for example 4 the word class label " $n$ - nomina' is placed after the main entry "ko.ba.la.min" and the label of field, 'Kim - kimia' before the meaning elaboration of that entry.

Example 3

ba.cut, ke.ba.cut $a d v$ cak telanjur

(KBBI4, 2011: 110) 
Example 4

ko.ba.la.min $n$ Kim vitamin $\mathrm{B}_{12}$, suatu senyawa

kompleks kobalt

(KBBI4, 2011: 710)

The finding has shown that the labels of language style and field exist in both dictionaries do exist in both the monolingual dictionaries. KBBI4 is less intensive in using the label of language style ( 84 entries) than KD4 (117 entries). For the label of field in KBBI4 (51 entries) the usage is more intensive compared to KD4 (45 entries). However, the shortcoming of KD4 is that it does not include important information which is word class label if compared with KBBI4. This causes the usage of word class to be very intensive for KBBI4 (994 entries). According to Ibrahim Ahmad (2006), the aspect of word usage label is diasystematic by nature. In the context of lexicography, the diasystematic information application is a comprehensive method which determines the limitation in using a word or phrase elaborated through the usage label.

\subsection{Etymology}

According to Fadilah Jasmani (1994: 5), etymology or the origin of the word revolves around the change of the form and/or the meaning of the word detected throughout the period of change, from the original language to the form and meaning of the target language. This aspect is included in the category of diachronic information (Hartmann \& James, 1998: 74). The Oxford English Dictionary in 12 volumes first published in 1928 is a pioneering dictionary that makes the effort to include etymology or word origin in its every entry. Etymology descriptions or word origin are found to exist in both dictionaries of study and placed after the main entry or root entry. However, the explanation is limited and brief for instance a word originates from a dialect, or a foreign word using the label of abbreviation only.

Some 305 entries $(28.06 \%)$ from the whole study data have this etymological aspect. From 305 entries, only 90 entries or $29.51 \%$ have etymologically original language in the same entry for both dictionaries. Next, 81 entries from the total of 90 entries have the same etymological descriptions and entries. Example 5 shows the same etymology for entry "ajak II, ${ }^{2}$ ajak". The explanation on this etymology is confined to the original language or word origin, or its abbreviation, placed after the main entry. The etymological original language of the Malay words in Example 5 comes from Minangkabau (Mn, Mk). The rest, or 9 entries with different etymological descriptions have the same entry, nonetheless. The data are displayed in Example 6. The entry for Example 6 "bacak $\mathbf{I},{ }^{\mathbf{1}} \mathbf{b a . c a k}$ " feeds on the word origin or etymology with the label of abbreviation after the main entry. As an instance, Example 6 namely "bacak I" in KD4 originates from Jakarta with the abbreviation Jk. Meanwhile in KBBI4, the entry "ba.cak" in Example 6 comes from Minangkabau with the label $M k$.

\section{$\underline{\text { Example } 5}$}

ajak II Mn sama dgn, seakan-akan, seperti, ...

(KD4, 2010: 20)

2ajak $M k$ p serupa (dng); seperti; ...

(KBBI4, 2011: 22) 
Example 6 2015, Vol. 3, No. 1

bacak I Jk lunak kerana banyak airnya (tanaman dll), basah.

(KD4, 2010: 100)

${ }^{1}$ ba.cak $M k$ a berbintik-bintik (tt bulu): ayam --

(KBBI4, 2011: 110)

The rest or 215 entries or $70.49 \%$ have their etymology but it is not contained in the same entry. Example 7 shows the entry "ajab" using an Arabic etymology with the label Ar after the root entry in KD4 (2010). However, the entry of "a.jab" in KBBI4 does not place any etymology in the entry. Both entries are the same in KD4 and KBBI4 but they do not have the same etymology. The entry in KD4 has etymology information but KBBI4 does not place any label of etymology after its main entry.

\section{Example 7}

ajab Ar sl hairan

(KD, 2010: 20)

a.jab a hairan

(KBBI4, 2011: 22)

The etymological explanation in KD4 is not thoroughly provided. It only goes on to state that the original language of a word has seeped into the Malay vocabulary, but its foreign characteristics are still felt, without insomuch considering the level or degree of permeation of the word among language users. This limited etymological information is hoped to be able to become the starting point of further studies on borrowing words. From the analysis of the study, the etymological information in KD4 can be referred in usage guideline and the total is 283 entries. Meanwhile, for KBBI4 it can be referred in adoption indicator totalling 111 lemma (word entry). The etymological explanations in KD4 and KBBI4 are shown in Table 2:

Table 2. Etymological Explanations in KD4 and KBBI4

\begin{tabular}{lllll}
\hline No. & Etymology (KD4) & Total. & Etymology (KBBI4) & Total. \\
\hline 1. & Ar - Arab & 59 & Mk - Minangkabau & 41 \\
2. & Mn - Minangkabau & 52 & Jw - Jawa & 24 \\
3. Jw - Jawa & 49 & Ar - Arab & 20 \\
4. & Jk - Jakarta & 44 & Jk - Melayu Jakarta & 16 \\
5. & IB - Indonesia Belanda & 39 & Cn - Cina & 2 \\
6. & Id - Indonesia & 22 & Sd - Sunda & 2 \\
7. & Kl - Kelantan & 7 & Brk - Berik & 1 \\
8. C - Cina & 7 & Sp - Spanyol & 1 \\
9. Ph-Pahang & 1 & Bk - Biak & 1 \\
10. NS - Negeri Sembilan & 1 & Bt - Batak & 1 \\
11. Pr - Perak & 1 & Plb - Palembang & 1 \\
12. Kd - Kedah & 1 & Mal - Melayu Malaysia & 1 \\
Total & 283 & Total & 111 \\
\hline
\end{tabular}


From this table, for KD4, the foreign language or Arabic makes up the most entries or 59 entries. This is followed by Minangkabau containing 52 entries and Javanese (49 entries). Next, we have 44 entries for Jakarta, Indonesian Dutch languages (39 entries), Indonesian (22 entries), Kelantanese (7 entries), Chinese (7 entries), and one entry each for languages of Pahang, Negeri Sembilan, Perak dan Kedah. The most is the Minangkabau Language in KBBI4 which is 41 lemma (word entry). The least is one entry in Berik, Spanish, Biak, Batak, Palembang and Malaysian Malay. The other lemma (word entry)s are Javanese (24 lemma (word entry)), Arabic (20 lemma (word entry)), Jakarta Malay (16 lemma (word entry)) and two entries in Sundanese and Chinese. All in all, KD4 uses more etymological information than KBBI4.

The explanation on the etymological information or the origin of words is apparent in both dictionaries. KD4 (283 entries) carries more entries as compared to KBBI4 (111 entries). Such information is substantial as a user cannot use a word effectively without knowing its root and origin. There are three purposes for having to have etymological information in dictionaries: to provide the information on the language history; to improve the understanding, either in the context of language in general and own language in particular; and to serve as a record of culture for one speaking in his or her own language other than providing evidence for the history of the culture and its relationships with others (Ibrahim Ahmad, 2006). The possibility is that etymological entries can contain anything either comprising of a brief statement from the closest sources to a complex essay tracing the history of a word from its original form in a language. Etymological information is crucial especially for native speakers who wish to know about the development of vocabulary over the years. This is why in any monolingual dictionary especially general dictionaries like Oxford English Advanced Learner's Dictionary, such piece of information is important for both non-native speakers and students.

\subsection{Cross-Reference}

Hartmann and James (1998: 74) in their study state that the cross-reference aspect is other information in the dictionary information category. Although cross-referencing is categorized as other information, it stands as one of the information that is important and essential in a dictionary, especially Malay monolingual dictionaries. This aspect gives notes of instruction or indicators to users so that they can refer to a section or other words. This seeks to further explain the meaning or perhaps, a given word that has the same meaning with the word in question. Actually, cross-referencing can be divided into two namely Explicit Cross-Reference and Implicit Cross-Reference. Thus, most dictionaries tend to use because the Explicit Cross-Reference as it is more accurate and that it can save up more space and word in a dictionary (Mohd. Rasdi, 2012: 13). The cross-reference symbol used in KD4 and KBBI4 is the same where it is in symbol form or arrow form $(\rightarrow)$.

In KD4, the symbol $(\rightarrow)$ bermakna see (KD4, 2010: xlix). The finding shows that only 63 entries (Refer to Attachment 1) in KD4 which use the cross-reference marks. The use of cross-referencing can be seen in two varying contexts. The first context is that users can find the meaning of an entry by directly cross-referencing to the root entry or termed Explicit 


\section{Macrothink}

Cross-Reference. 27 entries use the first context. The description of the first context is exhibited in Example 8:

Example 8

$$
\begin{array}{ll}
\text { dolim } \text { ark } \rightarrow \text { lalim. } & (K D 4,2010: 360) \\
\text { limbak } \rightarrow \text { lembak. } & (K D 4,2010: 940)
\end{array}
$$

In the context above, users can look up the meaning of the entry 'dolim' or 'limbak' by directly referring to the word 'lalim' or 'lembak'. For the second context, the cross-referencing is included after meaning is given or termed Implicit Cross-Reference. In the total number of data in this study, only 36 entries use the second context. Example 9 shows the second context:

\section{Example 9}

bendar parit (di sawah dll), longkang; menaikkan sondai

prb mempertahankan yg tidak mungkin dapat dipertahankan;

membendarkan mengalirkan sesuatu (air); bagai air ke bukit

prb pekerjaan yg sia-sia; $\rightarrow$ bandar II.

(KD4, 2010: 160)

The example above enables the users to get the meaning 'bendar' or 'parit (di sawah dll), longkang' directly or enables them to refer to 'bandar II'. Cross-reference is included after the description of meaning of an entry.

For KBBI4, the arrow $(\rightarrow)$ is also used as a marker for cross-referencing for unrecommended lemma (word entry), or for any lemma (word entry) variants which spelling is of a standard form (KBBI, 2011: xlii). KBBI4 has 74 entries (Refer to attachment 11) which use the cross-reference mark from the entire research data. All these entries use the first context where users can look up the meaning by directly making cross-reference to the root entry. Example 10 describes the information of the first context:

Example 10

$$
\begin{aligned}
& { }^{1} \text { bacak } \rightarrow \text { bacek } \\
& { }^{1} \text { bacang } \rightarrow \text { embacang }
\end{aligned}
$$

The similarity with both dictionaries is that they contain the cross-reference information of the first context namely direct cross-reference or Explicit Cross-reference. The plus point for KD4 is including the second-context cross-reference or Implicit Cross-reference which is indirect cross-reference in 36 entries of the study. The cross-referencing adopted in both the dictionaries aims at helping the users know the official spelling of an entry in particular classic words or borrowing words (Mohd. Rasdi, 2012). 


\section{Conclusion}

Having analysed both these monolingual dictionaries, it is found that both have fulfilled the most appropriate characteristics with their respective target users. Although there are only three aspects being studied, it is sufficient to expose the field or category of information in an entry covering both the linguistic or non-linguistic aspect in the Malay monolingual dictionaries. The study outcome demonstrates that there exist some differences, similarities and shortcomings in the information field of both dictionaries, KD4 (2010) and KBBI4 (2011). The dictionary makers have successfully included all basic information of an entry needed in the monolingual dictionary. It is found that both the dictionaries are able to serve as good and comprehensive points of reference for general use. Only the aspect of the arrangement or position is different in the information descriptions of an entry. In reality, there is yet to be an unflawed dictionary that can fulfill the needs of dictionary users. The strength of a dictionary can be seen in the field of information contained in the dictionary's own metalanguage. However, this heated dictionary practice to shift from one that is conventional (printed copy) to one that is electronic or in the form of digital copy will more or less influence the presentation and content of information of a dictionary entry (Tan Kim Hua \& Woods, 2008). Therefore, this study would be useful to users especially educators, students and academicians on the exposure of the importance of information field or category in the arrangement of a Malay monolingual dictionary. This enables the users of the dictionary to not be influenced by the name and the physical image of the dictionary alone. But they have the right and are able to evaluate information categories contained in a "good" dictionary. A good dictionary is the one with its arrangement method well-tailored to the needs of the target market (Rahim Mat Leh, 2000). Indirectly speaking, the Malay monolingual dictionary deemed as 'good' and 'comprehensive' will definitely enrich the knowledge of users in the Malay Language and continue to popularize the language in the international domain.

\section{References}

Asmah, H. O. (1987). Perkamusan Melayu: Satu Penilaian. Kuala Lumpur: Perpustakaan Universiti Malaya.

Asmah, H. O. (1993). Bahasa dan Alam Pemikiran Melayu. Kuala Lumpur: Dewan Bahasa dan Pustaka.

Dale, E. et al. (1971). Techniques of Teaching Vocabulary. California: Field Educational Publications, Inc.

Fadilah, J. (1994). Kategori Maklumat dalam Kamus. Kertas Kerja Seminar Perkamusan Melayu. 20-21 Disember. Kuala Lumpur: Dewan Bahasa dan Pustaka.

Harimurti, K. (1993). Kamus Linguistik. Jakarta: PT Gramedia Pustaka Utama.

Hartmann, R. R. K., \& Gregory, J. (1998). Dictionary of Lexicography. London: Routledge. http://dx.doi.org/10.4324/9780203159040 
Hishamudin, I., \& Norshimah, M. A. (2011). Analisis Berasaskan Korpus Dalam Menstruktur Semula Kedudukan Makna Teras Leksikal Setia. GEMA Online ${ }^{T M}$ Journal of Language Studies, 11(1), 143-158.

Ibrahim, A. (1991). Information field Perkamusan Melayu: Suatu Penilaian terhadap Kamus Dewan dan Kamus Besar Bahasa Indonesia. Jurnal Dewan Bahasa., 35 (7), 600-607.

Ibrahim, A. (1992). Kosa Kata Perkamusan Melayu. Pelita Bahasa. August, 14-16.

Ibrahim, A. (1994). Perkamusan Melayu: Suatu Pengenalan. Kuala Lumpur: Dewan Bahasa Pustaka.

Ibrahim, A. (2004). Perkamusan Melayu: Teori dan Amali. Kuala Lumpur: Universiti Malaya.

Ibrahim, A. (2006). Metabahasa Kamus untuk Penutur Asli dan Golongan Pelajar: Suatu Perbandingan. Dlm. Zubaidah Ibrahim, Abdul Rahim Mat Yassim \& Supramani a/l Shoniah (pnyt.), Kajian Bahasa dan Terjemahan. Kuala Lumpur: Universiti Malaya Publisher.

Lawrence, J. (1984). Some of Lexicography in SEA Englishes. Kertas Berkala. Singapura: Regional English Language Centre (RELC).

Kamus Besar Bahasa Indonesia Edisi Keempat. (2011). Jakarta: PT Gramedia Pustaka Utama.

Kamus Dewan Edisi Keempat. (2010). Kuala Lumpur: Dewan Bahasa dan Pustaka.

Mohd. Rasdi, S. (1994). Kamus Dewan dan Kamus Besar: Perbandingan Aspek Kandungan Information field. Retrieved from http://jpmipgmtaa.webs.com/Penulisan/KamusDewan_vs_KamusBesar_Jurnal_.pdf

Noresah, B. (1993). Kamus Dewan. Jurnal Dewan Bahasa, 37(12), 1120-1127.

Noresah, B. et al. (2009). Kamus dan Perkamusan Melayu. Kuala Lumpur: Dewan Bahasa dan Pustaka.

Rahim, M. L. (2000). Kamus Muktahir Bahasa Melayu: Satu Tinjauan Dari Segi Linguistik. Master Thesis in Arts. Serdang, Selangor: Universiti Putra Malaysia.

Tan, K. H., \& Woods, P. C. (2008). Media-related or generic-related features in electronic dictionaries: Learners. perception and preferences. GEMA Online ${ }^{T M}$ Journal of Language Studies, 8(2), 1-17.

Teeuw, A. (1964). Tentang Kamus dan Perkamusan Melayu. Jurnal Dewan Bahasa, 8(9), 388-397.

Yusof, H. (1961). Kamus Melayu Sejak 1511. Jurnal Dewan Bahasa, 5(4), 151-161. 
Attachment I

The Use of Direct and Indirect Cross-Reference in Entry KD4 2010

\begin{tabular}{|c|c|c|c|c|}
\hline No. & $\begin{array}{l}\text { Direct Cross-Reference } \\
\text { Entry }\end{array}$ & Pg. & $\begin{array}{l}\text { Indirect Cross-Reference } \\
\text { Entry }\end{array}$ & Pg. \\
\hline 1. & cincang I $\rightarrow$ cencang I & 280 & bendar $\rightarrow$ bandar II & 160 \\
\hline 2. & cingah $\rightarrow$ cingangah & 280 & bibit II $\rightarrow$ bimbit & 180 \\
\hline 3. & dolim $\rightarrow$ lalim & 360 & cambah $\rightarrow$ kecambah & 240 \\
\hline 4. & jelepak $\rightarrow$ jelepok & 620 & dadap II $\rightarrow$ dedap & 300 \\
\hline 5. & jubung $\rightarrow$ jerubung & 640 & daduh $\rightarrow$ dadung & 300 \\
\hline 6. & karunia $\rightarrow$ kurnia & 680 & dadung $\rightarrow$ daduh & 300 \\
\hline 7. & kecipung $\rightarrow$ kecimpung & 700 & jelepak $\rightarrow$ lepak I & 620 \\
\hline 8. & keringsing $\rightarrow$ geringsing & 760 & kakok $\rightarrow$ kakap V & 660 \\
\hline 9. & kerinting I $\rightarrow$ keriting & 760 & kecuak $\rightarrow$ kecoak & 700 \\
\hline 10. & kuya I $\rightarrow$ keria I & 860 & kelintang $\rightarrow$ kelentang & 720 \\
\hline 11. & lawar I $\rightarrow$ lawa I & 900 & kerip $\rightarrow$ kerit I & 760 \\
\hline 12. & lencet $\rightarrow$ lecet & 920 & kudidi $\rightarrow$ kedidi & 840 \\
\hline 13. & limbak $\rightarrow$ lembak & 940 & kutu II $\rightarrow$ sekutu & 860 \\
\hline 14. & luasa $\rightarrow$ leluasa & 960 & lenci I $\rightarrow$ laici & 920 \\
\hline 15. & menjelai $\rightarrow$ enjelai; jelai & 1020 & lenda $\rightarrow$ landa II & 920 \\
\hline 16. & mensiu $\rightarrow$ mesiu & 1020 & marut $\mathrm{I} \rightarrow$ carut & 1000 \\
\hline 17. & menta $\rightarrow$ meta I & 1020 & mengok $\rightarrow$ mengot & 1020 \\
\hline 18. & pegawam $\rightarrow$ peguam & 1160 & menjak $\rightarrow$ semenjak & 1020 \\
\hline 19. & puyuh III $\rightarrow$ puyu I & 1260 & menjana $\rightarrow$ semenjana & 1020 \\
\hline 20. & sambur $\rightarrow$ sabur & 1380 & menjelis $\rightarrow$ majlis II & 1020 \\
\hline 21. & sawo II $\rightarrow$ sawa I & 1400 & pohon II $\rightarrow$ mohon & 1220 \\
\hline 22. & Selan $\rightarrow$ sailan & 1420 & recak I $\rightarrow$ bercak & 1300 \\
\hline 23. & semilir $\rightarrow$ silir & 1440 & renyang $\rightarrow$ renyah II & 1320 \\
\hline 24. & sowan $\rightarrow$ soang & 1520 & renyeh I $\rightarrow$ ronyeh I & 1320 \\
\hline 25. & sowang $\rightarrow$ soang & 1520 & selampek $\rightarrow$ selampai I & 1420 \\
\hline 26. & tungkik $\rightarrow$ tukuk II & 1740 & seminau $\rightarrow$ sinau & 1440 \\
\hline 27. & tungkul II $\rightarrow$ tongkol & 1740 & setenggar $\rightarrow$ istinggar & 1480 \\
\hline 28. & & & sulur II $\rightarrow$ suluh I & 1540 \\
\hline 29. & & & sulut $\rightarrow$ sundut III & 1540 \\
\hline 30. & & & syurah $\rightarrow$ syarah II & 1560 \\
\hline 31. & & & talang $\mathrm{V} \rightarrow$ petalangan & 1580 \\
\hline 32. & & & tanggul I $\rightarrow$ anggul & 1600 \\
\hline 33. & & & tawarikh $\rightarrow$ tarikh & 1620 \\
\hline 34. & & & tembarau $\rightarrow$ teberau & 1640 \\
\hline 35. & & & tembera $\rightarrow$ tembera II & 1640 \\
\hline 36. & & & titir III $\rightarrow$ ketitir & 1700 \\
\hline
\end{tabular}


Attachment II

The Use of Direct Cross-Reference in Lemma (word entry) KBBI4 2011

\begin{tabular}{|c|c|c|c|c|c|}
\hline No. & Entry & Pg. & No. & Entry & Pg. \\
\hline 1. & ${ }^{2}$ alu $\rightarrow$ elu & 45 & 38. & menjelis $\rightarrow$ majelis & 901 \\
\hline 2. & ${ }^{2}$ bacak $\rightarrow$ bacek & 110 & 39. & mensiu $\rightarrow$ mesiu & 901 \\
\hline 3. & ${ }^{1}$ bacang $\rightarrow$ embacang & 110 & 40. & menta $\rightarrow$ meta & 901 \\
\hline 4. & ${ }^{1}$ bada $\rightarrow{ }^{1}$ bakda & 110 & 41. & mustak $\rightarrow$ musytak & 944 \\
\hline 5. & bendar $\rightarrow{ }^{1}$ bandar & 169 & 42. & mustami $\rightarrow$ mustamik & 944 \\
\hline 6. & bendel $\rightarrow{ }^{1}$ bundel & 169 & 43. & musykil $\rightarrow$ muskil & 944 \\
\hline 7. & ${ }^{1}$ bendari $\rightarrow$ bendahari & 169 & 44. & padi $\rightarrow$ pemadi & 1005 \\
\hline 8. & cingah $\rightarrow$ cingangah & 268 & 45. & pegawam $\rightarrow$ peguam & 1037 \\
\hline 9. & ${ }^{2}$ deras $\rightarrow$ daras & 317 & 46. & podak $\rightarrow$ pandan & 1086 \\
\hline 10. & dolat $\rightarrow$ daulat & 339 & 47. & ${ }^{1}$ puyu $\rightarrow{ }^{3}$ puyuh & 1125 \\
\hline 11. & dolim $\rightarrow$ zalim & 339 & 48 & ${ }^{1}$ renyai $\rightarrow$ rinai & 1166 \\
\hline 12. & ekopraksia $\rightarrow$ ekofraksia & 355 & 49. & sambur $\rightarrow$ sabur limbur & 1215 \\
\hline 13. & gadah $\rightarrow$ kadah & 403 & 50. & selampek $\rightarrow{ }^{1}$ selampai & 1248 \\
\hline 14. & jelentik $\rightarrow$ selentik & 575 & 51. & Selan $\rightarrow$ Sailan & 1248 \\
\hline 15. & jelepak $\rightarrow$ jelepok & 575 & 52. & semilir $\rightarrow{ }^{1}$ silir & 1263 \\
\hline 16. & jubung $\rightarrow$ jerubung & 590 & 53. & sepekuk $\rightarrow$ spekuk & 1279 \\
\hline 17. & kecindan $\rightarrow$ kecandan & 645 & 54. & sepet $\rightarrow$ sipit & 1280 \\
\hline 18. & kecipung $\rightarrow$ kecimpung & 645 & 55. & seteker $\rightarrow$ steker & 1294 \\
\hline 19. & kecuak $\rightarrow$ kecoak & 645 & 56. & ${ }^{2}$ singgung $\rightarrow{ }^{2}$ sigung & 1313 \\
\hline 20. & kendak $\rightarrow$ gendak & 667 & 57. & singkak $\rightarrow$ singkap & 1313 \\
\hline 21. & keringsing $\rightarrow{ }^{1}$ geringsing & 680 & 58. & sotor $\rightarrow$ sotoh & 1333 \\
\hline 22. & khabar $\rightarrow$ khabar & 692 & 59. & sowan $\rightarrow$ soang & 1333 \\
\hline 23. & ${ }^{1}$ kobak $\rightarrow$ kubak & 710 & 60. & sowang $\rightarrow$ soang & 1333 \\
\hline 24. & kudidi $\rightarrow$ kedidi & 750 & 61. & span $\rightarrow{ }^{1}$ sepan & 1333 \\
\hline 25. & kudi $\rightarrow$ kodi & 750 & 62. & spatbor $\rightarrow$ sepatbor & 1333 \\
\hline 26. & kudil $\rightarrow$ kudis & 750 & 63. & syurah $\rightarrow{ }^{2}$ syarah & 1369 \\
\hline 27. & ${ }^{2}$ lanca $\rightarrow$ lancia & 781 & 64. & syurga $\rightarrow$ surga & 1369 \\
\hline 28. & lencet $\rightarrow$ lecet & 812 & 65. & talai $\rightarrow$ lalai & 1383 \\
\hline 29. & lenga $\rightarrow$ bijan & 812 & 66. & talak $\rightarrow$ talk & 1383 \\
\hline 30. & luasa $\rightarrow$ leluasa & 844 & 67. & tawarikh $\rightarrow$ tarikh & 1413 \\
\hline 31. & marwah $\rightarrow$ muruah & 881 & 68. & ${ }^{1}$ tembel $\rightarrow$ timbil & 1430 \\
\hline 32. & marzipan $\rightarrow$ marsepen & 881 & 69. & ${ }^{2}$ tembel $\rightarrow$ tambal & 1430 \\
\hline 33. & mengok $\rightarrow$ mengot & 900 & 70. & tembera $\rightarrow$ tambera & 1431 \\
\hline 34. & menila $\rightarrow$ manila & 900 & 71. & ${ }^{3}$ titir $\rightarrow$ ketitir & 1474 \\
\hline 35. & menjak $\rightarrow$ semenjak & 901 & 72. & tungkik $\rightarrow{ }^{2}$ tukik & 1505 \\
\hline 36. & menjana $\rightarrow$ semenjana & 901 & 73. & ${ }^{2}$ tungkul $\rightarrow{ }^{1}$ tongkol & 1505 \\
\hline 37. & menjelai $\rightarrow$ enjelai; jelai & 901 & 74. & war $\rightarrow$ uar & 1556 \\
\hline
\end{tabular}




\section{Copyright Disclaimer}

Copyright for this article is retained by the author(s), with first publication rights granted to the journal.

This is an open-access article distributed under the terms and conditions of the Creative Commons Attribution license (http://creativecommons.org/licenses/by/3.0/). 